\title{
Kajian Penerapan Zona Pengendalian Lalu Lintas Pada Pelaksanaan Pekerjaan Jalan
}

\author{
Rio Andika ${ }^{1}$, Purnawan ${ }^{2}$, Elsa Eka Putri ${ }^{3}$ \\ Fakultas Teknik, Universitas Andalas ${ }^{1,2,3}$ \\ email: rioandika_c72@yahoo.co.id ${ }^{1}$,purnawan@gmail.com², elsaeka@gmail.com³ \\ DOI: http://dx.doi.org/10.31869/rtj.v3i2.1760
}

\begin{abstract}
Road works are almost close with moving traffic and potentially causing traffic disruption, congestion, delay, frustration, and more can cause collisions that would injure or kill road users and road workers. In order to remain resilient, the road worker must apply the zone concept on road works. This study aims to evaluate the application of Safety Technical Guidance on Road Work Location conducted by PT. Citra Muda Noer Bersaudara on Road Reconstruction of Junction (Koto Baru) - Jambi Border segment. So do a direct observation of the road work zone implemented by the contractor and compare it with the applicability in the guide. The implementation of the road work zone carried out by the contractor on the work package under review still lacks. In the implementation, the lack of which always occurs in every job implementation is the absence of a termination zone in all types of work, the transition zone is only applied to asphalt work, the early warning zone is only applied to road concrete work, asphalt overlay work and road shoulder work. Speed survey results show that the implementation of road work zone applied by the contractor can reduce the speed of the vehicle.
\end{abstract}

Keywords: Road works, zone concept, road safety, vehicle speed.

\section{PENDAHULUAN}

Pekerjaan jalan, baik itu berupa kegiatan pemeliharaan, rehabilitasi maupun pembangunan (pelebaran) jalan dapat menyebabkan gangguan fungsi jalan existing. Pekerjaan jalan hampir selalu berdekatan dengan lalu lintas yang bergerak, bahkan untuk jalan baru, yang akhirnya akan bergabung dengan jalan eksisting di ujungujungnya. Apabila zona kerja tersebut dekat dengan pergerakan lalu lintas, maka pekerjaan memiliki potensi menyebabkan terjadinya gangguan lalu lintas, kemacetan, tundaan/delay, frustasi, dan terlebih dapat menyebabkan tabrakan yang akan mencederai atau membunuh pengguna jalan dan/atau pekerja jalan. Oleh karena itu dibutuhkan perhatian khusus pada keselamatan jalan pada pekerjaan jalan berlangsung.

Dalam PP No. 34 tahun 2006 tentang jalan, Penyelenggara Jalan wajib menjaga kelancaran dan keselamatan lalu lintas selama pelaksanaan konstruksi jalan (Pasal 93). Pelaksanaan pemeliharaan jalan harus memperhatikan keselamatan pengguna jalan dengan penempatan perlengkapan jalan secara jelas sesuai dengan peraturan perundangundangan (Pasal 98).

Menurut Karim dan Adeli (2003) zona kerja merupakan suatu area dengan pembatasan sementara pada jalan raya yang memberikan dampak negatif lalu lintas jalan. Dampak tersebut dapat berupa kemacetan, meningkatnya waktu perjalanan, meningkatnya kecelakaan dan ketidakpuasan dari pengguna jalan. Zona kerja perlu diatur sedemikian rupa dan dikendalikan untuk mengurangi dampak tersebut. Dewi (2014) mengatakan bahwa konsep zona harus diterapkan untuk menciptakan lokasi pekerjaan jalan yang lebih berkeselamatan dan meningkatkan kenyamanan pengguna jalan saat melintasi lokasi pekerjaan jalan. Sudarsana dkk (2013) mengatakan terjadi penurunan kinerja jalan selama masa pelaksanaan rekonstruksi, seperti yang terjadi pada paket pekerjaan Rekonstruksi Jalan Batas Kota Negara - Pekutatan, Provinsi Bali tahun 2013. Dari hasil penelitian terjadi penurunan kapasitas jalan sebesar 32\%, kecepatan kendaraan pada jam puncak turun dari 40 $\mathrm{km} / \mathrm{jam}$ menjadi $35 \mathrm{~km} / \mathrm{jam}$, arus lalu lintas turun sebesar $18 \%$.

Dalam Work Zone Traffic Control Manual yang dikeluarkan oleh New York State Department Of Transportation (2015) dikatakan bahwa work zone adalah jarak antara rambu-rambu peringatan pertama dengan titik terluar area kerja dimana lalu lintas tidak lagi terpengaruh. Widjayanti (2009) mendefinisikan bahwa zona kerja (work zone) adalah suatu segmen dari ruas 
jalan yang ditutup pada sebagian lebar jalannya karena adanya suatu kegiatan kontruksi di jalan tersebut yang mengakibatkan penyempitan pada ruas jalan tersebut.

Direktorat Jenderal Bina Marga (2012) dalam Panduan Teknis Rekayasa Keselamatan Jalan mengatakan Konsep Zona adalah suatu metode pembagian lokasi pekerjaan menjadi lima zona terpisah berdasarkan fungsi. Dengan mempertimbangkan lima zona ini, desain kebutuhan manajemen lalu lintas dan perambuan untuk pekerjaan jalan menjadi jauh lebih jelas. Kelima zona tersebut adalah:

1. Zona Peringatan Dini adalah segmen jalan dimana pengguna jalan diinformasikan tentang akan adanya pekerjaan jalan dan apa yang harus dilakukan. Zona ini memperingatkan pengemudi/pengendara akan adanya pekerjaan jalan.

2. Zona Pemandu Transisi (Taper) adalah di zona ini pengemudi/pengendara diarahkan ke luar dari lintasan perjalanan normal. Zona ini digunakan untuk memandu pengemudi/pengendara masuk ke lintasan yang benar dan pada kecepatan yang tepat.

3. Area Kerja adalah tempat pekerjaan dilaksanakan secara fisik dan dimana terdapat pekerja, peralatan, perlengkapan, dan material.

4. Area Penyangga Keselamatan adalah area keselamatan longitudinal sebelum area kerja untuk meningkatkan perlindungan dan keselamatan pekerja. Area bebas ini umumnya mempunyai panjang sedikitnya 20 meter, namun dapat diperpanjang jika area kerja tersembunyi dari pengguna jalan akibat ada tikungan atau jalan cembung. Area ini juga termasuk penyangga lateral yang sempit di samping area kerja untuk memberikan perlindungan tambahan bagi pekerja.

5. Zona Terminasi adalah zona dimana lalu lintas kembali normal setelah melalui lokasi pekerjaan.

Lima konsep zona diatas dapat diperkecil menjadi empat konsep zona. Area kerja dan area penyangga keselamatan dapat diklasifikasikan sebagai satu zona kerja. Konsep zona pekerjaan jalan dapat dilihat pada ilustrasi gambar 1 .

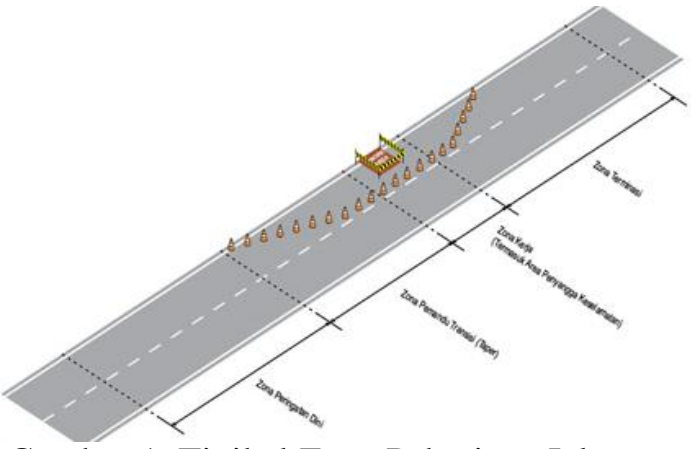

Gambar 1. Tipikal Zona Pekerjaan Jalan

Manajemen lalu lintas pada zona kerja (work zone) merupakan hal yang penting dan mutlak dilakukan selama adanya pekerjaan jalan. Walaupun hanya kegiatan pemeliharaan rutin ataupun kegiatan rehabilitasi wajib dilakukan manajemen lalu lintas selama kegiatan tersebut apalagi untuk kegiatan yang komplek seperti pembangunan (pelebaran) jalan. Manajemen lalu lintas pada zona kerja (work zone) sudah mendapat perhatian khusus oleh negara - negara maju seperti Amerika dan negara - negara di Eropa. Negara - negara tersebut telah memiliki panduan (manual) pengaturan lalu lintas pada zona kerja jalan yang menjadi acuan bagi pelaksana pekerjaan jalan dalam melakukan pengaturan lalu lintas selama pekerjaan jalan.

Pemerintah Indonesia melalui Kementerian Pekerjaan Umum juga telah memiliki panduan untuk melakukan pengaturan lalu lintas selama pekerjaan jalan seperti Serial Rekayasa Keselamatan Jalan, Panduan Teknis 3 Keselamatan Di Lokasi Pekerjaan, tahun 2012. Namun pada pelaksanaannya di lapangan masih belum sesuai dengan yang diharapkan. Oleh karena itu, perlu dilakukan penelitian untuk mengetahui penerapan pelaksanaan manajemen pada zona kerja yang dilakukan oleh kontraktor serta menganalisis kekurangan yang dilakukan oleh kontraktor tersebut.

Penelitian ini bertujuan untuk mengevaluasi penerapan Panduan Teknis Keselamatan di Lokasi Pekerjaan Jalan yang dilakukan oleh kontraktor PT. Citra Muda Noer Bersaudara pada Paket Rekonstruksi Jalan Ruas Junction (Koto Baru) - Batas Jambi. Manfaat penelitian adalah untuk mengetahui fakta lapangan terhadap penerapan Panduan Teknis Keselamatan di Lokasi Pekerjaan Jalan. 
Penelitian ini dilakukan pada proyek pada ruas jalan nasional di lingkungan Satuan Kerja Pelaksanaan Jalan Nasional Wilayah II Provinsi Sumatera Barat, yaitu pada ruas jalan nasional wilayah Dharmasraya (Ruas Junction (Koto Baru) - Bts. Jambi). Penelitian ini mengacu pada Panduan Teknis Keselamatan di Lokasi Pekerjaan Jalan (buku 3), Direktorat Jenderal Bina Marga, Kementerian Pekerjaan Umum. Lokasi penelitian dapat dilihat pada gambar 2.

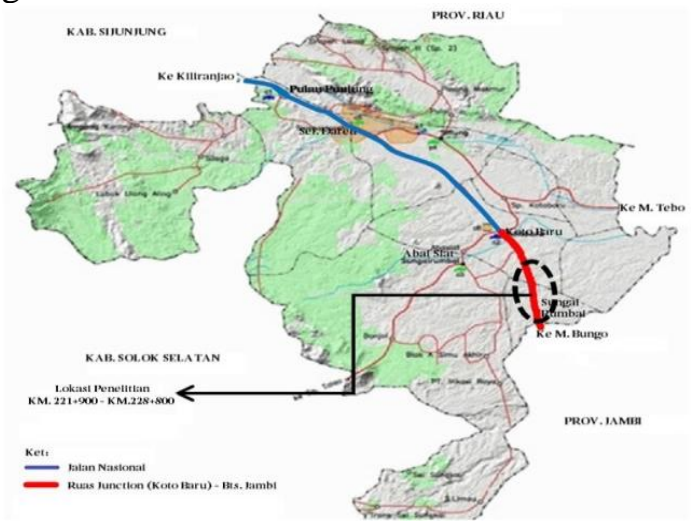

Gambar 2. Peta Lokasi Penelitian

\section{METODE PENELITIAN}

Penelitian ini merupakan penelitian deskriptif yaitu penelitian yang berusaha menginterpretasikan sesuatu. Untuk itu dilakukan survei langsung dilapangan untuk mengetahui penerapan zona pekerjaan jalan yang dilaksanakan oleh kontraktor dan membandingkannya dengan penerapan yang ada dalam panduan. Data diperoleh dengan melakukan survey lapangan pada lokasi proyek yang sedang berlangsung. Pelaksananaan pengamatan atau survey lapangan dimaksudkan untuk mengumpulkan data dan masukan mengenai kondisi eksisting jalan saat adanya pekerjaan jalan dan bagaimana pengendalian lalu lintas pada saat pelaksanaan pekerjaan seperti penggunaan rambu maupun pembagian zona.

Selain itu juga dilakukan pengambilan data kecepatan kendaraan sebelum memasuki lokasi pekerjaan dan pada saat melewati lokasi pekerjaan dengan menggunakan alat speed gun. Pengolahan data kecepatan dilakukan dengan menggunakan metoda kecepatan kendaraan pada $85^{\text {th }}$ persentil untuk mendapatkan kecepatan yang digunakan oleh $85 \%$ pengguna jalan.

Mcshane dan Roess (1990) mengatakan kecepatan $85^{\text {th }}$ persentil dapat digunakan untuk menentukan batas kecepatan kendaraan karena secara umum merupakan kecepatan yang digunakan oleh pengendara di jalan dan masih dapat diterima oleh sebagian besar pengguna jalan. Kecepatan $85^{\text {th }}$ persentil adalah kecepatan pada atau di bawah $85 \%$ dalam berkendara. Kecepatan diasumsikan terdistribusi normal.

\section{HASIL DAN PEMBAHASAN \\ Kecepatan Kendaraan Sebelum Lokasi Pekerjaan}

Data kecepatan kendaraan diperoleh dari hasil survey langsung di lapangan menggunakan alat speed gun. Survey kecepatan dilakukan untuk mengetahui kecepatan kendaraan sebelum dan sesudah lokasi pekerjaan jalan. Pengambilan data kecepatan dilakukan dari jam 6 pagi sampai jam 6 sore. Data kecepatan diambil untuk kecepatan kendaraan sebelum memasuki lokasi pekerjaan jalan Pengambilan data kecepatan dilakukan pada lokasi yang berada $500 \mathrm{~m}$ sebelum lokasi pekerjaan jalan.

Data kecepatan kendaraan yang telah dikumpulkan selanjutnya akan dianalisa dengan metoda kecepatan $85^{\text {th }}$ persentil. Penggunaan metoda kecepatan $85^{\text {th }}$ persentil bertujuan untuk memperoleh rata - rata kecepatan yang digunakan oleh $85 \%$ pengguna jalan. Dari hasil perhitungan dapat diperoleh kecepatan $85^{\text {th }}$ persentil seluruh kendaraan sebelum lokasi pekerjaan yaitu 56 $\mathrm{km} / \mathrm{jam}$ dengan kecepatan $85^{\text {th }}$ persentil sepeda motor sebelum lokasi pekerjaan yaitu 59 $\mathrm{km} / \mathrm{jam}$ dan $53 \mathrm{~km} / \mathrm{jam}$ untuk mobil. Hasil pengolahan data kecepatan dengan metoda $85^{\text {th }}$ persentil dapat dilihat pada gambar 3 .

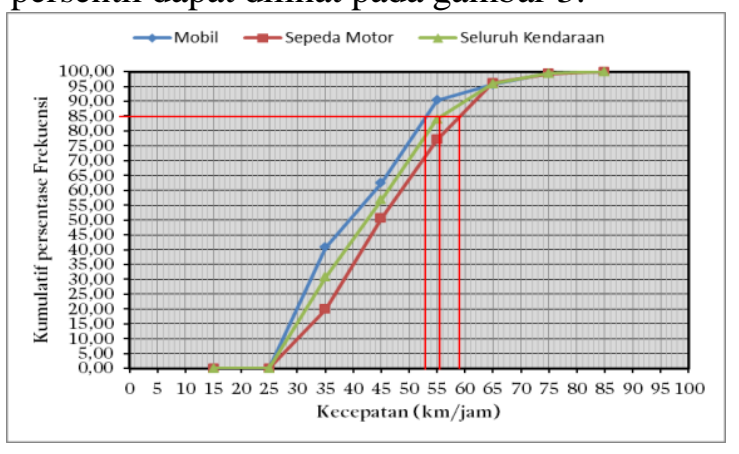

Gambar 3. Persentil $85^{\text {th }}$ dari kecepatan seluruh kendaraan sebelum lokasi pekerjaan 
Penerapan zona pekerjaan jalan pada pekerjaan perkerasan beton

Penerapan zona pekerjaan jalan pada pekerjaan perkerasan beton dapat dilihat pada gambar 4. Zona peringatan dini sudah diterapkan dengan panjang $100 \mathrm{~m}$ dan telah memenuhi syarat minimal panjang zona peringatan dini yaitu $75 \mathrm{~m}$. Terdapat 3 jenis rambu yang digunakan yaitu 2 buah rambu peringatan ada pekerjaan jalan, 1 buah rambu peringatan penyempitan jalan dan 1 buah rambu larangan mendahului. Terdapat seorang pengendali lalu lintas (flagman) sebelum memasuki zona kerja. Tidak ada zona pemandu transisi dan zona terminasi.

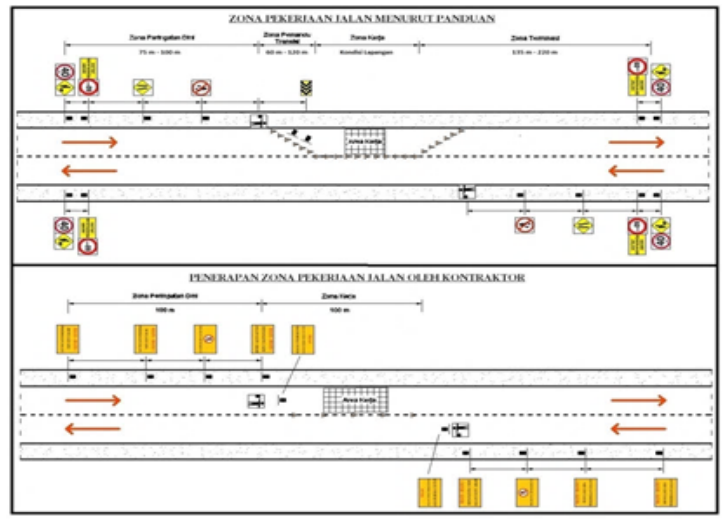

Gambar 4. Penerapan zona pekerjaan jalan pada pekerjaan perkerasan beton

Kecepatan $85^{\text {th }}$ persentil kendaraan pada lokasi pekerjaan beton yaitu $33 \mathrm{~km} / \mathrm{jam}$, dengan kecepatan $85^{\text {th }}$ persentil sepeda motor yaitu $34 \mathrm{~km} / \mathrm{jam}$ dan $32 \mathrm{~km} / \mathrm{jam}$ untuk mobil. Hasil pengolahan data kecepatan dengan metoda $85^{\text {th }}$ persentil pada lokasi pekerjaan beton dapat dilihat pada gambar 5 .

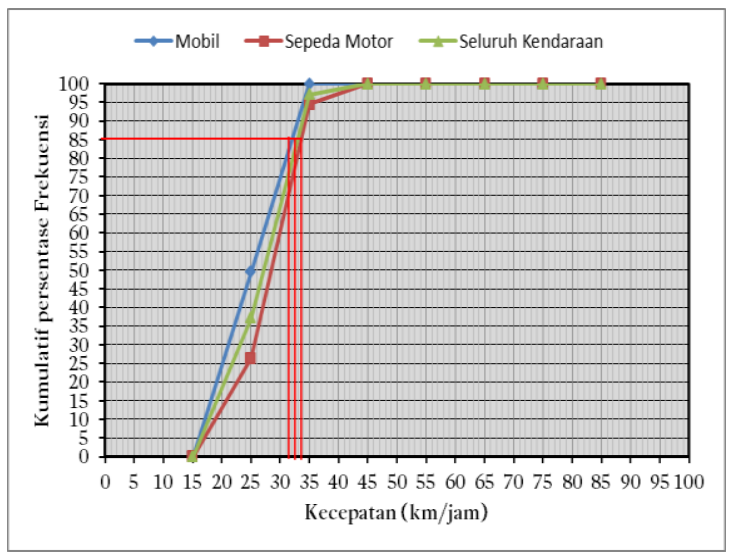

Gambar 5. Persentil $85^{\text {th }}$ dari kecepatan kendaraan di lokasi pekerjaan perkerasan beton
Penerapan zona pekerjaan jalan pada pekerjaan perkerasan aspal

Penerapan zona pekerjaan jalan pada pekerjaan perkerasan aspal dapat dilihat pada gambar 6. Zona peringatan dini sudah diterapkan dengan panjang $250 \mathrm{~m}$ dan telah memenuhi syarat minimal panjang zona peringatan dini yaitu $75 \mathrm{~m}$. Hanya terdapat 1 buah Rambu peringatan ada pekerjaan jalan yang ditempatkan di awal zona peringatan dini yakni $250 \mathrm{~m}$ dari zona kerja. Zona peringatan dini yang terlalu panjang namun hanya dilengkapi dengan 1 buah rambu sehingga tidak memberikan pengguna jalan informasi yang cukup tentang apa yang akan dihadapinya di depan. Sehingga masih banyak pengguna jalan yang tidak melambat saat melewati zona kerja. Zona pemandu transisi terlalu pendek yaitu $20 \mathrm{~m}$ tidak memenuhi syarat panjang minimal zona pemandu transisi yaitu $60 \mathrm{~m}-120 \mathrm{~m}$. Tidak ada zona terminasi.

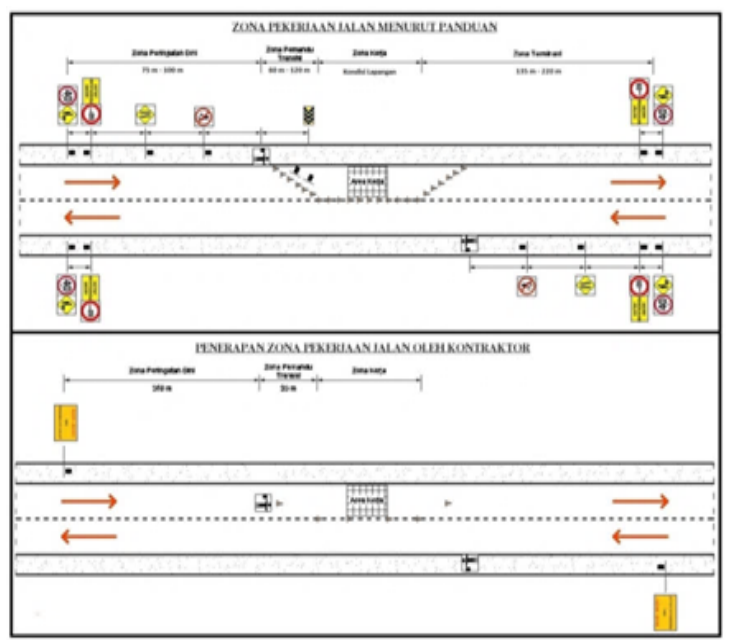

Gambar 6. Penerapan zona pekerjaan jalan pada pekerjaan perkerasan aspal

Kecepatan $85^{\text {th }}$ persentil kendaraan pada lokasi pekerjaan aspal yaitu $44 \mathrm{~km} / \mathrm{jam}$, dengan kecepatan $85^{\text {th }}$ persentil sepeda motor yaitu $47 \mathrm{~km} / \mathrm{jam}$ dan $42 \mathrm{~km} / \mathrm{jam}$ untuk mobil. $54 \%$ sepeda motor melaju dibawah $40 \mathrm{~km} / \mathrm{jam}$ dan $46 \%$ lainnya melaju diatas $40 \mathrm{~km} / \mathrm{jam} .80$ $\%$ mobil melaju di bawah $40 \mathrm{~km} / \mathrm{jam}$ dan $20 \%$ diatas $40 \mathrm{~km} / \mathrm{jam}$. Hasil pengolahan data kecepatan dengan metoda $85^{\text {th }}$ persentil pada lokasi pekerjaan aspal dapat dilihat pada gambar 7 . 


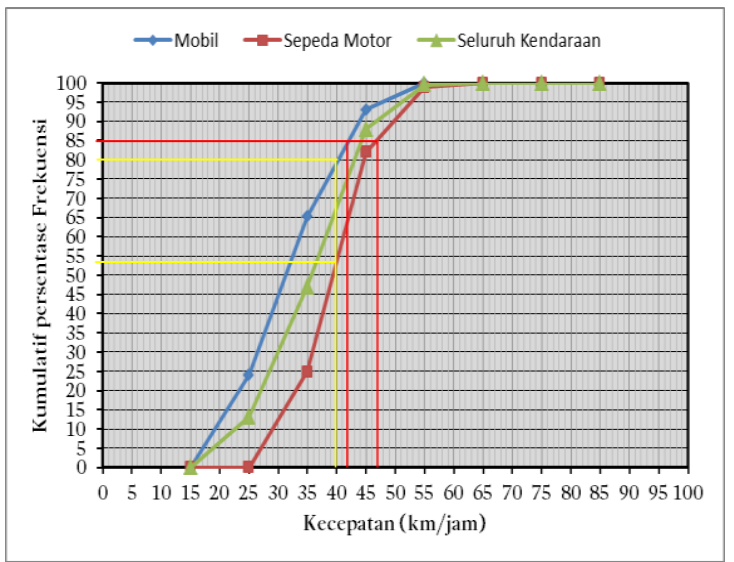

Gambar 7. Persentil $85^{\text {th }}$ dari kecepatan kendaraan di lokasi pekerjaan perkerasan aspal

\section{Penerapan zona pekerjaan jalan pada pekerjaan perkerasan bahu jalan}

Penerapan zona pekerjaan jalan pada pekerjaan bahu jalan dapat dilihat pada gambar 8. Zona peringatan dini sudah diterapkan dengan panjang $100 \mathrm{~m}$ dan telah memenuhi syarat minimal panjang zona peringatan dini yaitu $75 \mathrm{~m}$. Hanya terdapat 1 buah rambu peringatan ada pekerjaan jalan yang ditempatkan di awal zona peringatan dini yakni $100 \mathrm{~m}$ dari zona kerja. Dengan hanya 1 buah rambu tidak memberikan pengguna jalan informasi yang cukup tentang apa yang akan dihadapinya di depan. Sehingga banyak pengguna jalan yang tidak melambat saat melewati zona kerja. Tidak ada zona pemandu transisi dan zona terminasi.

Kecepatan $85^{\text {th }}$ persentil kendaraan pada lokasi pekerjaan bahu yaitu $50 \mathrm{~km} / \mathrm{jam}$, sedangkan kecepatan $85^{\text {th }}$ persentil sepeda motor yaitu $51 \mathrm{~km} / \mathrm{jam}$ dan $49 \mathrm{~km} / \mathrm{jam}$ untuk mobil. $40 \%$ sepeda motor melaju dibawah 40 $\mathrm{km} / \mathrm{jam}$ dan $60 \%$ lainnya melaju diatas 40 $\mathrm{km} / \mathrm{jam} .71 \%$ mobil melaju di bawah 40 $\mathrm{km} / \mathrm{jam}$ dan $29 \%$ diatas $40 \mathrm{~km} / \mathrm{jam}$. Hasil pengolahan data kecepatan dengan metoda $85^{\text {th }}$ persentil pada lokasi pekerjaan bahu jalan dapat dilihat pada gambar 9 .

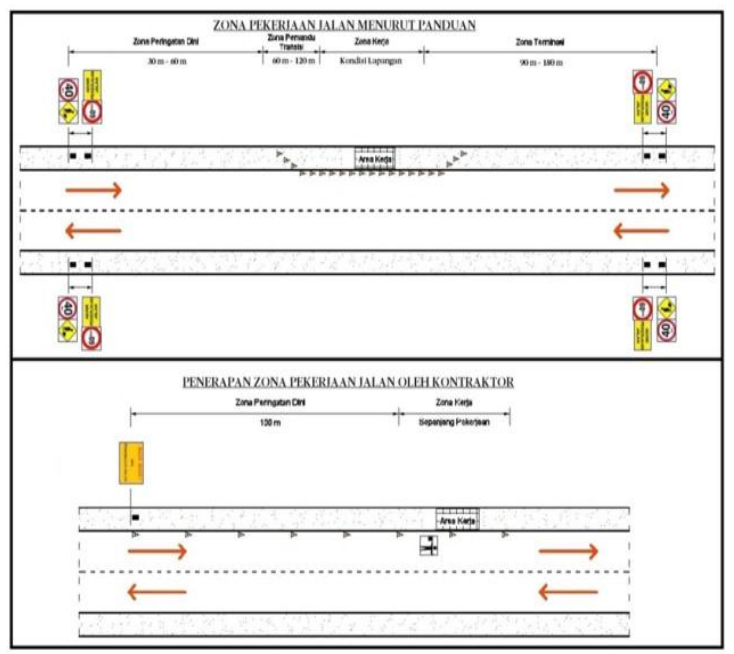

Gambar 8. Penerapan zona pekerjaan jalan pada pekerjaan bahu jalan

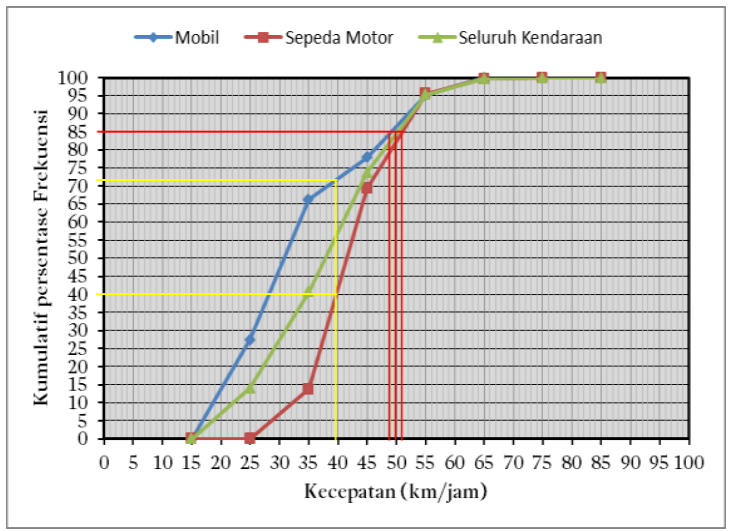

Gambar 9. Persentil $85^{\text {th }}$ dari kecepatan kendaraan di lokasi pekerjaan bahu jalan

\section{Penerapan zona pekerjaan jalan pada pekerjaan perkerasan saluran}

Penerapan zona pekerjaan jalan pada pekerjaan saluran dapat dilihat pada gambar 10. Tidak ada zona peringatan dini, zona pemandu transisi dan zona terminasi. Tidak terdapat rambu peringatan ada pekerjaan jalan namun terdapat 1 buah rambu adanya tumpukan material. Adanya rambu tumpukan material tidak memberikan pengguna jalan informasi yang cukup tentang apa yang akan dihadapinya di depan. Sehingga banyak pengguna jalan yang tidak melambat saat melewati zona kerja.

Kecepatan $85^{\text {th }}$ persentil kendaraan pada lokasi pekerjaan saluran yaitu $48 \mathrm{~km} / \mathrm{jam}$, sedangkan kecepatan $85^{\text {th }}$ persentil sepeda motor yaitu $49 \mathrm{~km} / \mathrm{jam}$ dan $47 \mathrm{~km} / \mathrm{jam}$ untuk mobil. $50 \%$ sepeda motor melaju dibawah 40 $\mathrm{km} / \mathrm{jam}$ dan $50 \%$ lainnya melaju diatas 40 
$\mathrm{km} / \mathrm{jam} .70 \%$ mobil melaju di bawah 40 $\mathrm{km} / \mathrm{jam}$ dan $30 \%$ diatas $40 \mathrm{~km} / \mathrm{jam}$. . Hasil pengolahan data kecepatan dengan metoda $85^{\text {th }}$ persentil pada lokasi pekerjaan saluran dapat dilihat pada gambar 11 .

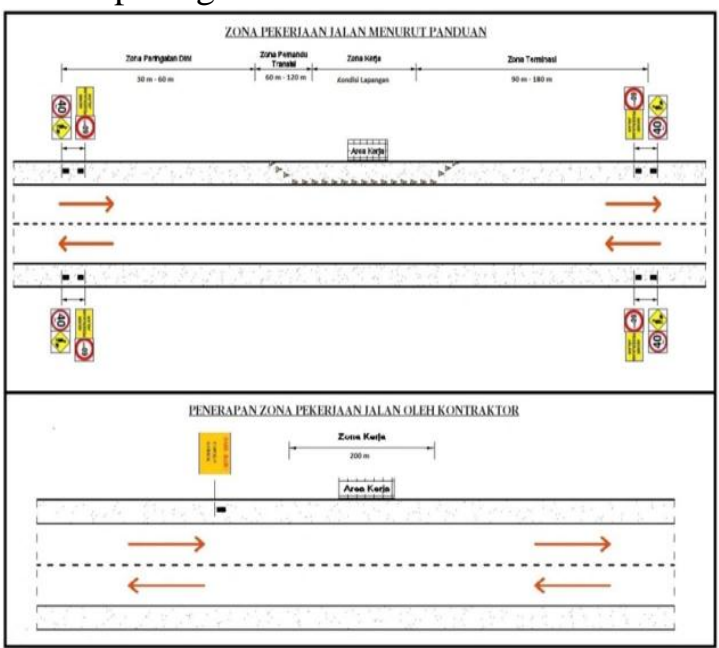

Gambar 10. Penerapan zona pekerjaan jalan pada pekerjaan saluran

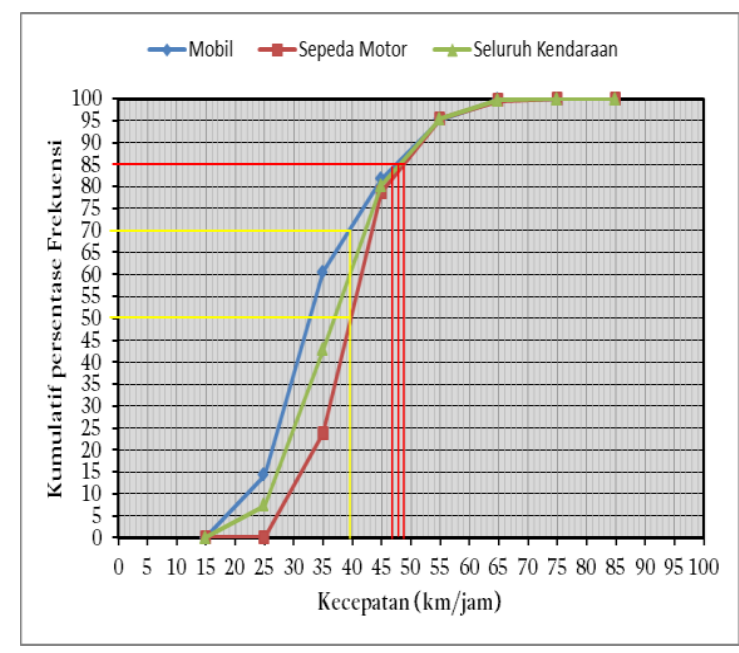

Gambar 11. Persentil $85^{\text {th }}$ dari kecepatan kendaraan di lokasi pekerjaan saluran

\section{Penerapan zona pekerjaan jalan pada pekerjaan perkerasan patching}

Penerapan zona pekerjaan jalan pada pekerjaan patching dapat dilihat pada gambar 12. Tidak ada zona peringatan dini, zona pemandu transisi dan zona terminasi. Tidak terdapat satupun rambu yang menginformasikan pengguna jalan akan ada pekerjaan jalan. Pengguna jalan mengetahui adanya pekerjaan jalan pada saat melewati zona kerja sehingga tidak memberikan cukup waktu bagi pengguna jalan untuk menurunkan kecepatan kendaraanya.

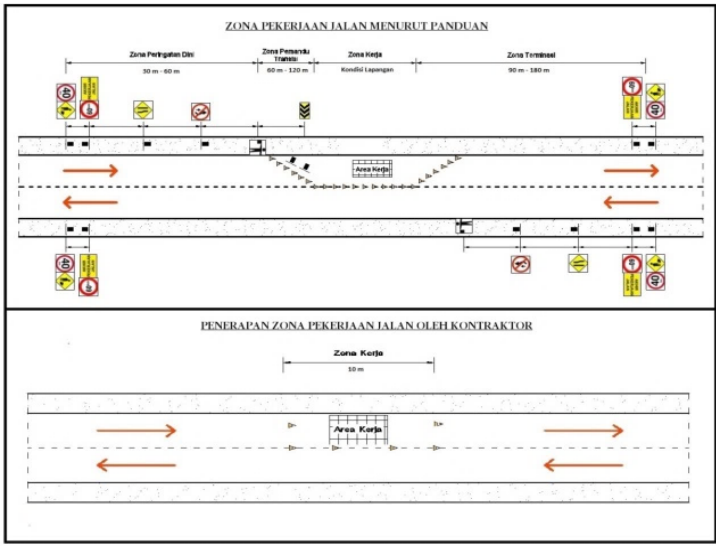

Gambar 12. Penerapan zona pekerjaan jalan pada pekerjaan patching

Kecepatan $85^{\text {th }}$ persentil kendaraan pada lokasi pekerjaan patching yaitu $50 \mathrm{~km} / \mathrm{jam}$, sedangkan kecepatan $85^{\text {th }}$ persentil sepeda motor yaitu $52 \mathrm{~km} / \mathrm{jam}$ dan $48 \mathrm{~km} / \mathrm{jam}$ untuk mobil. $43 \%$ sepeda motor melaju dibawah 40 $\mathrm{km} / \mathrm{jam}$ dan $57 \%$ lainnya melaju diatas 40 $\mathrm{km} / \mathrm{jam} .68 \%$ mobil melaju di bawah 40 $\mathrm{km} / \mathrm{jam}$ dan $32 \%$ diatas $40 \mathrm{~km} / \mathrm{jam}$. Hasil pengolahan data kecepatan dengan metoda $85^{\text {th }}$ persentil pada lokasi pekerjaan patching dapat dilihat pada gambar 13.

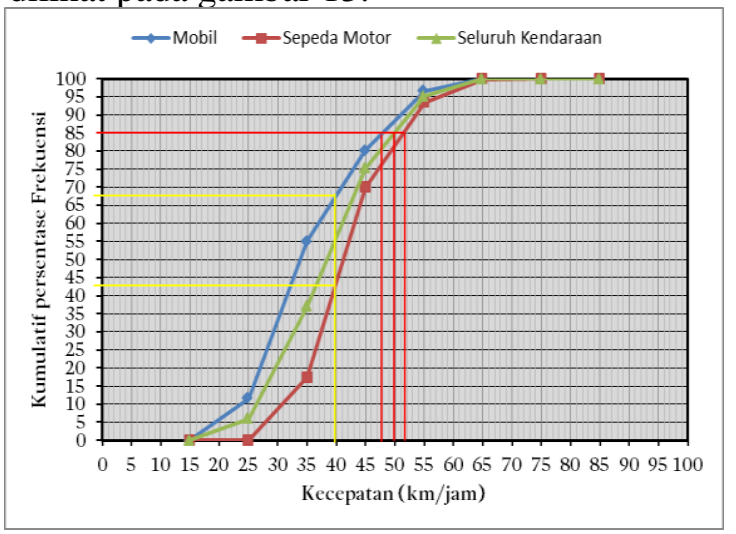

Gambar 13. Persentil $85^{\text {th }}$ dari kecepatan kendaraan di lokasi pekerjaan patching

\section{Penerapan zona pekerjaan jalan pada pekerjaan marka}

Penerapan zona pekerjaan jalan pada pekerjaan marka dapat dilihat pada gambar 14 . Tidak ada zona peringatan dini, zona pemandu transisi dan zona terminasi. Tidak terdapat satupun rambu yang menginformasikan pengguna jalan akan ada pekerjaan jalan. Pengguna jalan mengetahui adanya pekerjaan jalan pada saat melewati zona kerja sehingga tidak memberikan cukup waktu bagi pengguna jalan untuk menurunkan kecepatan kendaraanya. 


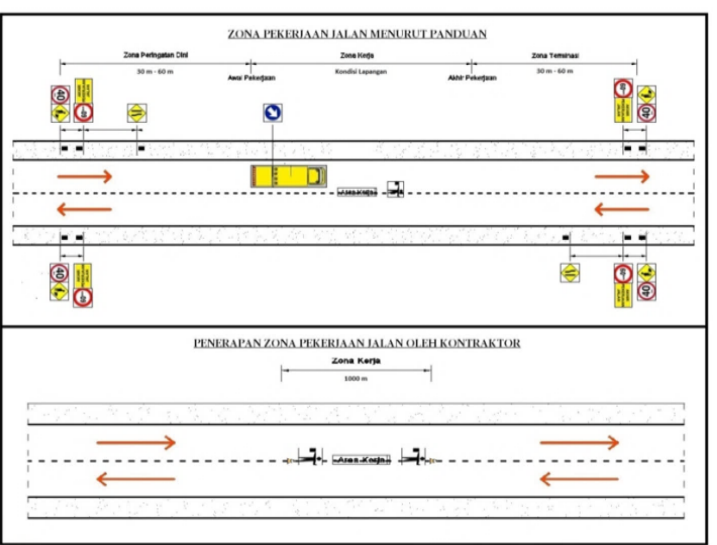

Gambar 14. Penerapan zona pekerjaan jalan pada pekerjaan marka

Kecepatan $85^{\text {th }}$ persentil kendaraan pada lokasi pekerjaan saluran yaitu $52 \mathrm{~km} / \mathrm{jam}$, sedangkan kecepatan $85^{\text {th }}$ persentil sepeda motor yaitu $53 \mathrm{~km} / \mathrm{jam}$ dan $51 \mathrm{~km} / \mathrm{jam}$ untuk mobil. $43 \%$ sepeda motor melaju dibawah 40 $\mathrm{km} / \mathrm{jam}$ dan $57 \%$ lainnya melaju diatas 40 $\mathrm{km} / \mathrm{jam} .55 \%$ mobil melaju di bawah 40 $\mathrm{km} / \mathrm{jam}$ dan $35 \%$ diatas $40 \mathrm{~km} / \mathrm{jam}$. Hasil pengolahan data kecepatan dengan metoda $85^{\text {th }}$ persentil pada lokasi pekerjaan beton dapat dilihat pada gambar 15 .

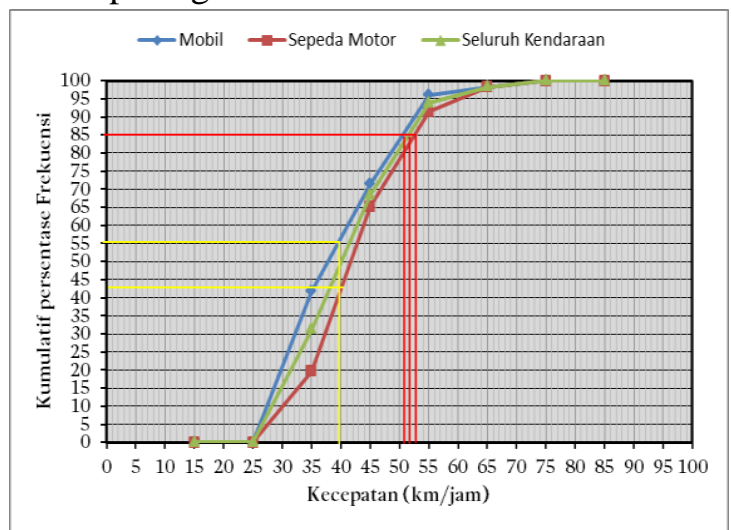

Gambar 15. Persentil $85^{\text {th }}$ dari kecepatan kendaraan di lokasi pekerjaan marka

\section{Rekomendasi pelaksanaan penerapan zona pengendalian lalu lintas}

Pengendalian lalu lintas pada zona pekerjaan jalan merupakan suatu kewajiban yang harus dilakukan oleh kontraktor pelaksana pekerjaan jalan. Dalam dokumen kontrak Paket Rekonstruksi Jalan Junction (Koto Baru) - Bts. Jambi diperoleh informasi bahwa terdapat mata pembayaran khusus untuk melaksanakan pengendalian lalu lintas. Namun pada pelaksanaannya terlihat seadanya, hal ini disebabkan karena kurangnya pengendalian dari direksi pekerjaan yang masih mengutamakan progres fisik tapi kurang memperhatikan faktor keselamatan jalan.

Seperti yang dijelaskan dalam Spesifikasi Umum 2010 revisi 3, seksi 1.8 Manajemen dan Keselamatan Lalu Lintas, butir 1.8.2.3, dikatakan bahwa jika pengendalian lalu lintas tidak disediakan, tidak dipelihara, atau tidak dilaksanakan, direksi pekerjaan dapat mengambil tindakan untuk perbaikan dan membebankan biayanya kepada kontraktor. Oleh karena itu, kepada Direksi Pekerjaan agar selalu melakukan evaluasi penerapan zona pengendalian lalu lintas pada lokasi pekerjaan pada rapat mingguan dan direkomendasikan untuk dapat mengambil tindakan perbaikan dan membebankan biayanya kepada kontraktor seperti yang dijelaskan dalam spesifikasi umum.

\section{PENUTUP}

Penerapan zona pengendalian lalu lintas pada pekerjaan jalan yang dilakukan oleh kontraktor pada paket pekerjaan yang sedang ditinjau masih kurang. Kekurangan yang selalu terjadi tidak adanya zona terminasi di semua jenis pekerjaan. Zona transisi hanya diterapkan untuk pekerjaan aspal. Zona peringatan dini hanya diterapkan untuk pekerjaan perkerasan beton, pekerjaan perkerasan aspal dan bahu jalan.

Hasil survei kecepatan menunjukkan bahwa penerapan zona pengendalian lalu lintas pada pekerjaan jalan dapat mengurangi kecepatan kendaraan. Penerapan zona pekerjaan jalan pada saat pekerjaan overlay beton menurunkan kecepatan kendaraan sesuai dengan syarat kecepatan pada zona kerja hingga dibawah $40 \mathrm{~km} / \mathrm{jam}$. Penerapan zona pekerjaan jalan pada saat pekerjaan overlay aspal, bahu, saluran, patching dan marka belum menurunkan kecepatan kendaraan hingga dibawah $40 \mathrm{~km} / \mathrm{jam}$.

\section{DAFTAR PUSTAKA}

Dewi,R,(2014), Evaluasi Penyelenggaraan Pekerjaan Jalan Terkait Keselamatan Dengan Konsep Zona, Universitas Gajah Mada, Yogyakarta.

Direktorat Jenderal Bina Marga, (2010), Spesifikasi Umum 2010 Revisi 3, Jakarta. 
Direktorat Jenderal Bina Marga, (2012), Panduan Teknis 3 Keselamatan di Lokasi Pekerjaan Jalan, Kementerian Pekerjaan Umum, Jakarta.

Karim, A and Adeli, H, (2003), CBR Model for Freeway Work Zone Traffic Management, Journal of Transportation Engineering, Vol. 129, No. 2, March, 2003.

Mcshane, Wiliam $\mathrm{R}$ and Roess, Roger $\mathrm{P}$ (1990), Traffic Engineering, Englewood Cliffs, New Jersey.

New York State Departement Of Transportation (NYSDOT), (2015), Work Zone Traffic Control Manual, New York.

Pemerintah Republik Indonesia, (2006), Peraturan Pemerintah Republik Indonesia Nomor 34 Tahun 2006 Tentang Jalan, Jakarta.

Sudarsana, D.K, dkk, (2013), Kajian Kinerja Jalan Akibat Adanya Zona Kerja (Work Zone). Prosiding The 16th FSTPT International Symposium, UMS Surakarta.

Widjajanti, (2009), Kontrol Lalu Lintas Bersinyal di Lokasi Penyempitan Ruas Jalan pada Kondisi Arus Lalu Lintas Lewat Jenuh, Disertasi Teknik Sipil, Universitas Indonesia, Jakarta. 